\title{
Surgery for massive malignant tumors of the left atrium - one center's experience
}

\author{
Uladzimir Andrushchuk ${ }^{1}$, Youry Ostrovsky ${ }^{1}$, Vladimir Zharkov $^{2}$, Siarhei Amelchanka ${ }^{1}$, Valery Krutau $^{1}$, \\ Olga Yudina ${ }^{3}$, Tatsiana Ilyina ${ }^{1}$, Irina Grinchuk ${ }^{1}$ \\ ${ }^{1}$ Department of Cardiac Surgery, Republican Scientific Practical Center 'Cardiology', Minsk, Republic of Belarus \\ ${ }^{2}$ Department of Thoracic Surgery, Republican Scientific Practical Center of Oncology and Medical Radiology of N.A. \\ Alexandrova, Minsk, Republic of Belarus \\ ${ }^{3}$ Pathology Department, Health Care Institution, City Clinical Pathology Bureau, Minsk, Republic of Belarus
}

Kardiochirurgia i Torakochirurgia Polska 2016; 13 (3): 229-235

\begin{abstract}
Introduction: Surgery for primary non-resectable malignant tumors of the left atrium is controversial. Today heart autotransplantation as a method of surgical treatment for patients suffering primary massive malignant tumors of the left atrium is still not sufficiently studied.

Material and methods: We provide information on our singlecenter 5-year experience in performing surgical interventions for massive malignant tumors of the left atrium and including cases of 5 patients ( 3 males $-60 \%$, 2 females $-40 \%$ ). One case $(1 / 5,20 \%)$ involved debulking surgery with partial resection of the left atrial (LA) wall and its reconstruction using a xenopericardium patch. Orthotopic heart transplantation was performed in 1 patient $(1 / 5,20 \%)$ and heart autotransplantation $(\mathrm{HA})$ in the 3 other cases $(3 / 5,60 \%)$.

Results: Mean myocardial ischemia duration was $165.6 \pm 12.0$ minutes (range: 137-198), cardiopulmonary bypass (CPB) duration was $248.6 \pm 36.6$ minutes (range: $188-392$ ), and intervention duration was $498.0 \pm 77.4$ minutes (range: $330-780$ ). Mean total blood loss was estimated to be $2432 \pm 616.5 \mathrm{ml}$ (range: 1610-4880). Major in-hospital complications were registered in 4 patients $(4 / 5,80 \%)$. In-hospital mortality was registered in 3 patients $(3 / 5,60 \%)$. Survival time in $2(2 / 5,40 \%)$ patients discharged from the hospital was 29 and 9 months, respectively. Both died because of disease progression.

Conclusions: Surgery in patients with massive resectable primary malignant tumor of the left atrium is associated with high incidence of major hospital complications and mortality. Heart autotransplantation with radical tumor resection is the treatment of choice for these cases. The surgical approach implies thorough primary hemostasis and selection of a proper surgical approach, allowing revision of all the regions of intervention during each step. The possibility of excessive tension and bleeding in the area of bicaval anastomosis should be considered when performing heart autotransplantation, and appropriate preventive measures should be applied.
\end{abstract}

Key words: cardiac sarcoma, heart transplantation, autotransplantation.

\section{Streszczenie}

Wstęp: Chirurgiczne leczenie pierwotnych nieoperacyjnych złośliwych guzów lewego przedsionka (LA) jest przedmiotem dyskusji. Autotransplantacja serca jako chirurgiczna metoda leczenia chorych z rozległym guzem nowotworowym w obrębie lewego przedsionka jest wciąż niewystarczająco poznana. Materiat i metody: W badaniu zgromadzono dane z pojedynczego ośrodka, w którym w ciągu 5 lat leczono chirurgicznie 5 chorych z rozległym guzem złośliwym w obrębie lewego przedsionka (3 mężczyzn - 60\%, 2 kobiety - 40\%). W jednym przypadku (1/5, 20\%) operacja objęła częściową resekcję guza i ściany LA i jego rekonstrukcję z użyciem obcogatunkowej łaty osierdziowej. Ortotopowy przeszczep serca wykonano u 1 chorego (1/5, 20\%), a autotransplantację serca w 3 pozostałych przypadkach.

Wyniki: Średni czas niedokrwienia wyniósł $165,6 \pm 12,0$ minut (przedział: 137-198), czas krążenia pozaustrojowego 248,6 $\pm 36,6$ minuty (przedział: 188-392), czas zabiegu 498,0 $\pm 77,4$ minuty (przedział: 330-780). Średnia utrata krwi wyniosła $2432 \pm 616,5 \mathrm{ml}$ (przedział: 1610-4880). Poważne powikłania wewnątrzszpitalne wystąpiły u 4 chorych (4/5, 80\%), z których 3 zmarło $(3 / 5,60 \%)$. Czas przeżycia po wypisie ze szpitala u 2 pozostałych chorych wyniósł odpowiednio 29 i 9 miesięcy. Obydwoje chorzy zmarli wskutek progresji choroby.

Wnioski: Operacje u chorych z masywnym pierwotnym złośliwym guzem lewego przedsionka wiążą się z częstym występowaniem poważnych powikłań wewnątrzszpitalnych i wysoką śmiertelnością. Transplantacja serca z radykalną resekcją guza jest metodą z wyboru w tych przypadkach. Interwencja chirurgiczna wymaga zachowania hemostazy i właściwej techniki zabiegowej umożliwiającej odpowiednią rewizję wszystkich obszarów podczas każdego etapu operacji. W przypadku zastosowania podczas transplantacji metody bikawalnej należy się liczyć z możliwością wystąpienia nadmiernego napięcia i krwawienia w miejscu zespolenia.

Słowa kluczowe: mięsak serca, transplantacja serca, autotransplantacja.

Address for correspondence: Siarhei Amelchanka, Department of Cardiac Surgery, Republican Scientific Practical Center 'Cardiology', Minsk, Republic of Belarus, phone: +37 5297848684, fax: +37 5172861466, e-mail: omelchenkosergey2@gmail.com

Received: 15.04.2016, accepted: 21.09.2016. 


\section{Introduction}

Primary tumor of the heart is a rare pathology with the frequency of occurrence according to autopsy data ranging between $0.0017 \%$ and $0.28 \%$. Ninety percent of them are benign tumors and myxoma accounts for about $50 \%$ of these [1]. Sarcoma is the most frequent among malignant tumors, ranging between $0.001 \%$ and $0.03 \%$ of all autopsy cases, or $75 \%$ of all cardiac malignancies [2], with angiosarcoma (up to 37\%) and unclassified sarcomas (up to 24\%) being the most frequent [3]. Cardiac sarcoma is more frequent in males $(2: 1)$ aged 30 to 50 years [4]. The tumor is initially asymptomatic and in most cases is revealed after becoming massive and causing the first clinical signs: cardiac decompensation (due to intracardiac flow obstruction), embolism after tumor fragmentation, heart rhythm disturbances caused by tumor infiltration and compression of Purkinje's fibers. This pathology is characterized by poor outcome - mean life expectancy is about 11 months $[5,6]$. The main treatment method is surgical eradication of the tumor in conjunction with adjuvant polychemotherapy $(\mathrm{PCT})$, allowing one to achieve an increase of life expectancy compared to patients not operated on [7].

There are three known surgical strategies for patients with primary massive malignant tumors of the left atrium (PMMTLA). The first one is to open the left atrium (LA) leaving the heart in situ, with subsequent resection and reconstruction of the affected atrial wall portion. This strategy is more appropriate for small tumors. The second strategy - orthotopic heart transplantation - is limited by the availability of a donor heart. The effect of immune suppression on remaining tumor cells is also unknown [8]. The third strategy is a heart autotransplantation $(\mathrm{HA})$, allowing resection of the tumor-affected left atrial wall under good visual control. This strategy is not restricted by the availability of a donor heart and is devoid of risks associated with immunosuppression [9]. Heart autotransplantation in humans was initially used to provide heart denervation in vasospastic angina [10]. The first heart autotransplantation in a patient with a benign tumor was performed by Cooley in 1985 [11], and the first HA in a patient with a primary malignant tumor of the heart was performed by Reardon in 1998 [12]. Today HA is one of the treatment methods for patients with a massive primary malignant tumor of the LA. At the same time, local recurrence of an LA tumor even after pathology proven radical resection (RO) is the main cause of mortality in the early and midterm postoperative period [13].

This report provides our surgical experience in PMMTLA.

\section{Material and methods \\ Patients}

Five patients with PMMTLA were surgically treated in SI RSPC Cardiology of Republic of Belarus during the period from November 2011 to May 2015 (3 males - 60\%, 2 females -40\%). Patients' age ranged between 22 and 73 (48.4 \pm 9.9$)$ years. Mean body mass index was $28.5 \pm 2.4(23.5-35.8) \mathrm{kg} /$ $\mathrm{m}^{2}$. Dyspnea was prevalent among other complaints (in 4 out of 5 patients, $80 \%$ ). Syncope was present in 2 patients (in 2/5, 40\%), and leg edema, general weakness, and heart rhythm disturbances in the form of atrial fibrillation paroxysms were each present in 1 patient (1/5, 20\%). Three patients had cardiac failure of New York Heart Association (NYHA) functional class II $(3 / 5,60 \%)$, and NYHA III and IV were each registered in 1 patient $(1 / 5,20 \%)$. Neoadjuvant PCT was administered in 1 patient $(1 / 5,20 \%)$, who previously received surgical treatment for LA sarcoma. Transthoracic echocardiography (EchoCG) showed left ventricular ejection fraction to be $58.2 \pm 2.5$ (49-64)\%, mitral regurgitation in 3 cases was considered trivial (3/5,60\%), and moderate and severe regurgitation were each registered in 1 patient $(1 / 5,20 \%)$. Left atrium tumor size varied from 25/33 to 79/103 $\mathrm{mm}$ according to preoperative transthoracic and transesophageal EchoCG data, and data of cardiac computed tomography with bolus contrasting (CTA) or magnetic resonance imaging (MRI), used in all the cases with diagnostic purposes.

\section{Description of patients}

\section{Patient 1}

A 22-year-old male patient referred to our hospital in November, 2011, complaining of dyspnea on moderate physical exertion and a periodic syncopal condition. The LA neoplasm 40/60/50 cm with irregular shape, involving mitral annulus and posterior leaflet, was revealed (Fig. 1) in the patient according to transthoracic and transesophageal EchoCG, and cardiac CTA results.

Results of brain, thoracic and abdominal computed tomography (CT), and bone scintigraphy revealed no distant metastases. Heart autotransplantation with mitral valve replacement using a $31 \mathrm{~mm}$ mechanical prosthesis was performed on day 5. Mean myocardial ischemia (MIsc) duration was 198 minutes, and cardiopulmonary bypass (CPB) duration was 231 minutes. Three xenopericardium patches were used to repair the LA defect - two were used to make an anastomosis with the left and right pulmonary veins (PV), and the third was used to repair the LA portion around the mitral prosthesis. One more patch was used to elongate the superior vena cava. Intraoperative blood loss was $1,600 \mathrm{ml}$, and total blood loss on the first day was 2,050 ml. Respiratory support duration after the intervention was 3 hours 40 minutes, and length of the intensive care unit (ICU) stay was 5 days. Intraoperative urgent pathomorphological study revealed sarcoma. Final pathomorphological study confirmed malignant fibrous histiocytoma GIII with malignant cells in the resection margin (R1). The patient was discharged on day 16 after the intervention in satisfactory condition. In accordance with pathomorphological study results the patient underwent adjuvant radiotherapy with total radiation dose of $40 \mathrm{~Gy}$. The patient was followed up and died 29 months after the intervention, in the setting of disease progression with brain and lung distant metastases, but without obvious signs of continued local cardiac tumor growth. 


\section{Patient 2}

Female patient, 30 years old, admitted to our hospital in May, 2014 complaining of weakness and dyspnea on moderate exertion. Non-radical resection of LA tumor was performed in February, 2011 in a Minsk regional hospital. Intraoperative examination revealed tumor spread to right pulmonary veins' ostia, a large portion of the LA wall and part of the interatrial septum. Pathology diagnosis - pleomorphic rhabdomyosarcoma GIII. During the period from June 2014 the patient underwent four PCT courses (epirubicin $200 \mathrm{mg}$, carboplatin $750 \mathrm{mg}$, vincristine $2 \mathrm{mg}$ ). Subsequently the patient was followed up and felt well until April 2014 (38 months). Results of transthoracic echocardiography (EchoCG), transesophageal EchoCG and CTA results revealed neoplasm of irregular shape, 32/30/25 mm, in LA, spreading to interatrial septum, mitral annulus and anterior mitral leaflet (Fig. 2).

In abdominal CTA and bone scintigraphy no additional neoplasms were revealed. Heart autotransplantation, tumor resection with resection of adjacent portion of LA wall (resection margin $1.5-2 \mathrm{~cm}$ from the visible tumor), resection of interatrial septum, resection and bioprosthetic replacement of mitral valve were performed on day 7 (Medtronic Mosaic-29). Myocardial ischemia duration was 144 minutes, and CPB duration was 208 minutes. Two xenopericardium patches were used to repair the LA and interatrial septum, and another one was used to repair the inferior vena cava. Intraoperative blood loss was $1,550 \mathrm{ml}$, and total blood loss on day 1 was $1,880 \mathrm{ml}$. Respiratory support duration was 3.5 hours, and duration of ICU stay was 1.5 days. The postoperative period was complicated by the arrest of sinus node with syncopal condition requiring pacemaker implantation on day 20. Results of pathology examination: pleomorphic malignant fibrous histiocytoma GIII with primitive osteogenesis foci with clear resection margin (R0). Tumor immunophenotype: ALK - S100 - panck - Caldesmin - SMA - SMA+/- Aesmin - CD68++ Myogenin - Vim +++ CD3+ CD34 - Ki67 up to 10\%. The patient was discharged from the hospital in satisfactory condition on day 30. She was followed up and died 9 months after HA (February 6, 2015) secondary to distant lung metastases and recurrence of LA tumor.

\section{Patient 3}

Male patient, 51 years old, referred to our hospital in February, 2015, complaining of dyspnea on moderate exertion during the last 6 months, and periodic syncopal condition and paroxysmal atrial fibrillation during the last 2 months. Echocardiography data (Fig. 3) and cardiac CTA data (Fig. 4) revealed a tumor (69/60/48 mm) of the LA with signs of inferior left PV invasion, prolapsing during a systole into the left ventricular cavity and causing moderate functional mitral stenosis.

Coronarography revealed vascularization of the tumor from the circumflex artery and right coronary artery. Additional examination (brain MRI, thoracic and abdominal CTA, bone scintigraphy) did not reveal any distant metas-

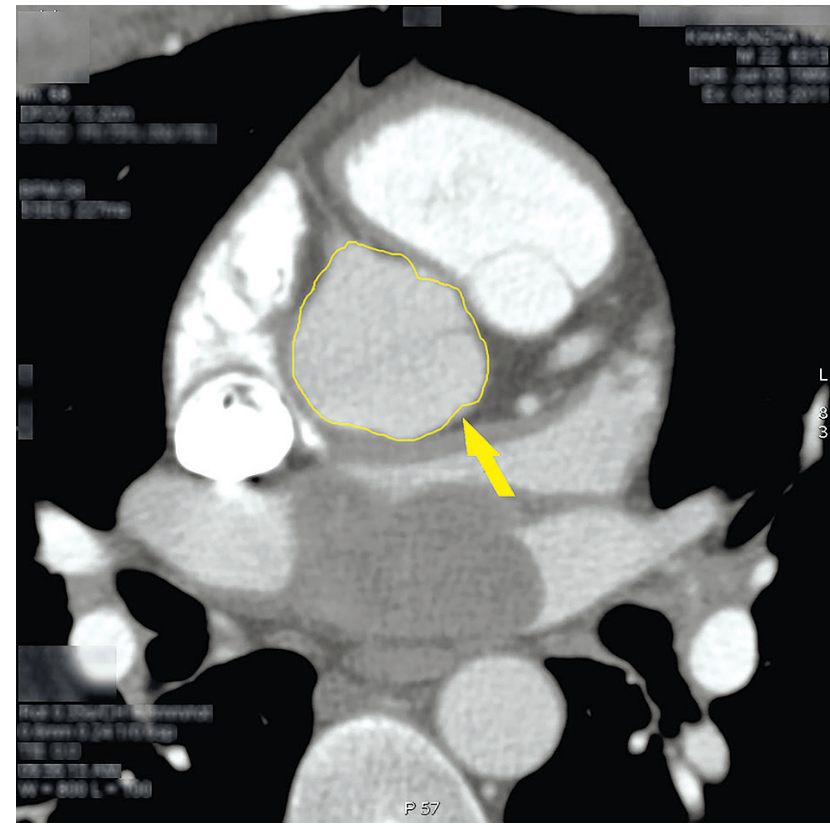

Fig. 1. Large tumor of the left atrium (CTA)

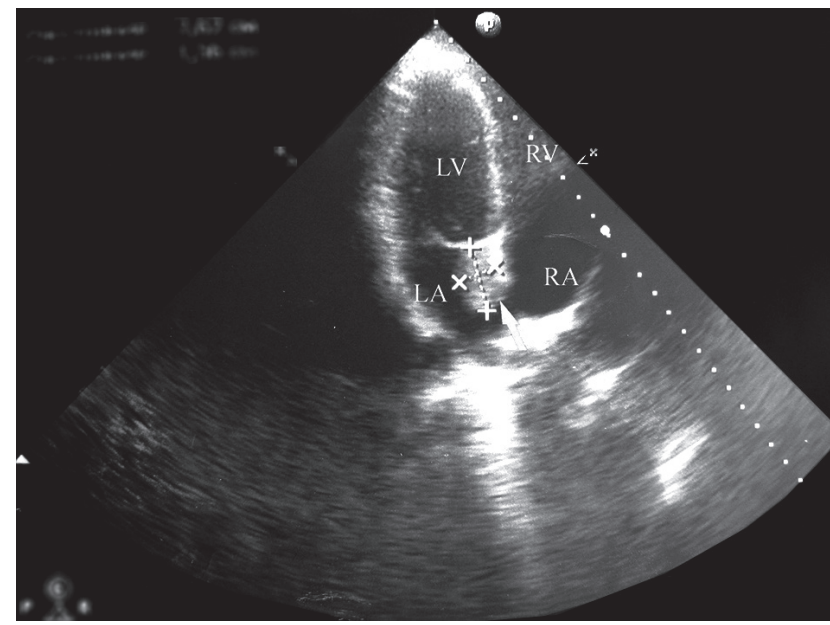

Fig. 2. Continued LA tumor growth (transthoracic EchoCG)

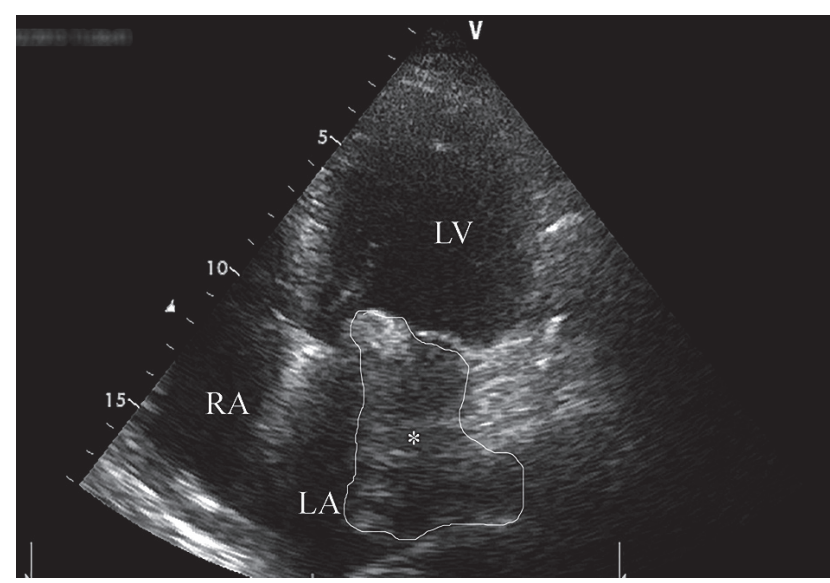

Fig. 3. Large tumor of the left atrium (transthoracic EchoCG)

tases. On day 3 surgical intervention was performed using sternotomy as a surgical approach: explantation of intact parts of the heart, removal of tumor-affected portion of the 


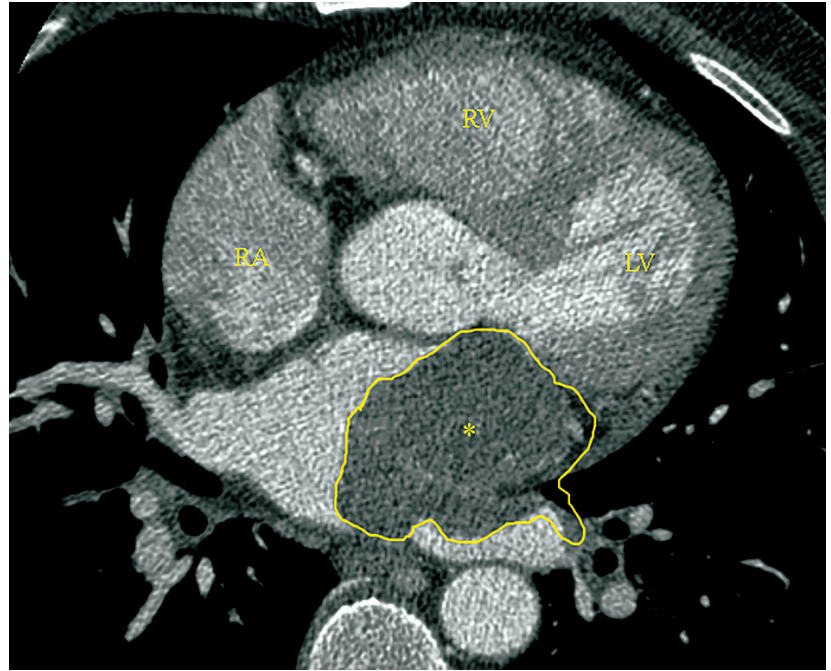

Fig. 4. Large tumor of the left atrium (CTA)

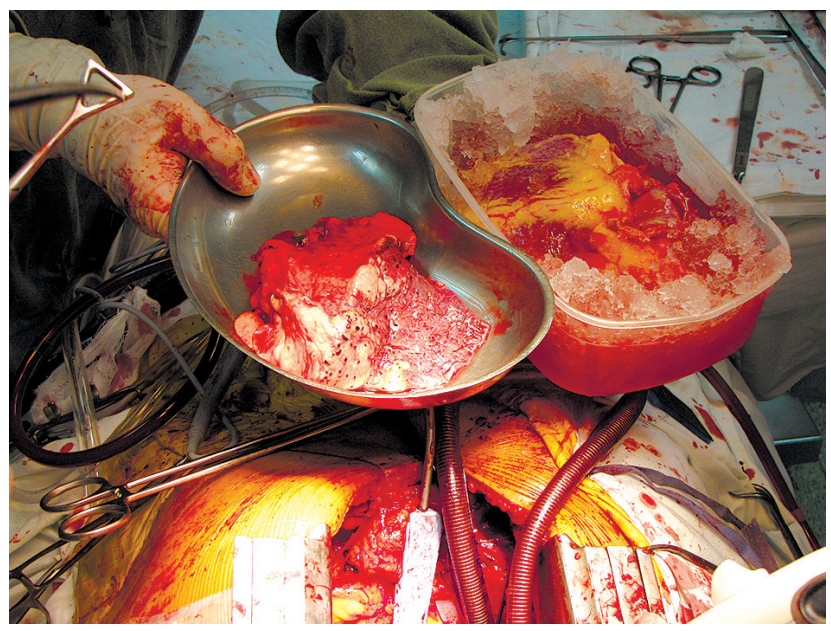

Fig. 6. Resected lower lobe of the left lung with a portion of the left atrium invaded by tumor and explanted heart

LA (Fig. 5) with its subsequent reconstruction using a xenopericardial patch, inferior left lobectomy (Fig. 6), and reconstructive suture annuloplasty of mitral and tricuspid valve (Fig. 7). After HA coronary bypass grafting was performed using an autovein for revascularization of the circumflex artery which was deformed in the area of LA reconstruction. Myocardial ischemia time was $187 \mathrm{~min}$, and CPB time was 382 min (prolonged CPB was required to perform coronary artery bypass grafting because of intraoperative myocardial infarction and heart failure). Two xenopericardium patches were used to repair the LA defect: the first one to make an anastomosis with the left upper pulmonary vein, and the second one to repair the LA. Intraoperative blood loss was 2,400 ml. On day 1 resternotomy with thoracotomy was performed because of continued bleeding. Total blood loss on day 1 was 4,880 $\mathrm{ml}$, which required intense substitution therapy with blood components. Duration of respiratory support after the intervention was 8.0 hours. Blood ultrafiltration treatment lasting 6 days was used because of acute renal failure. The patient died 17 days after

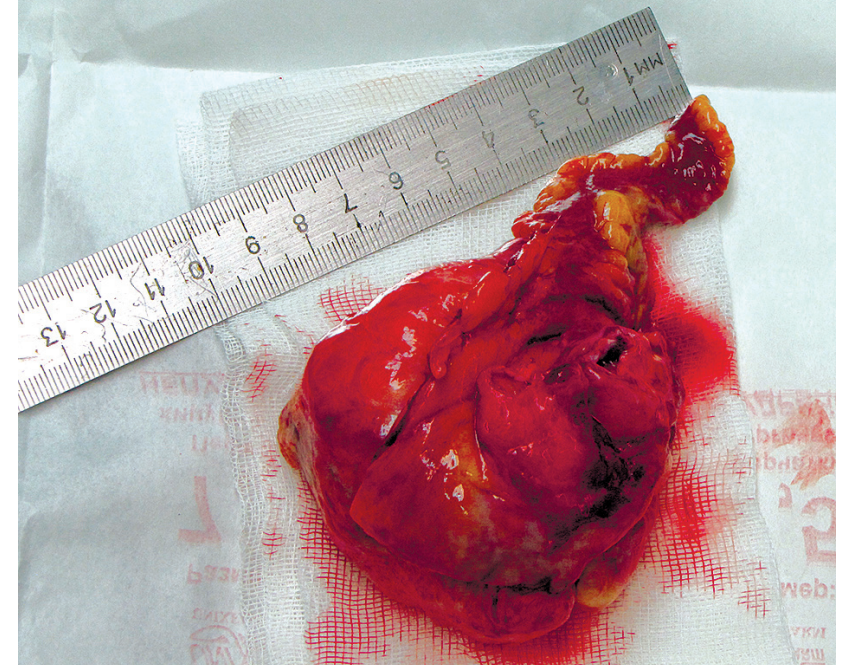

Fig. 5. Resected tumor with a portion of left atrial wall

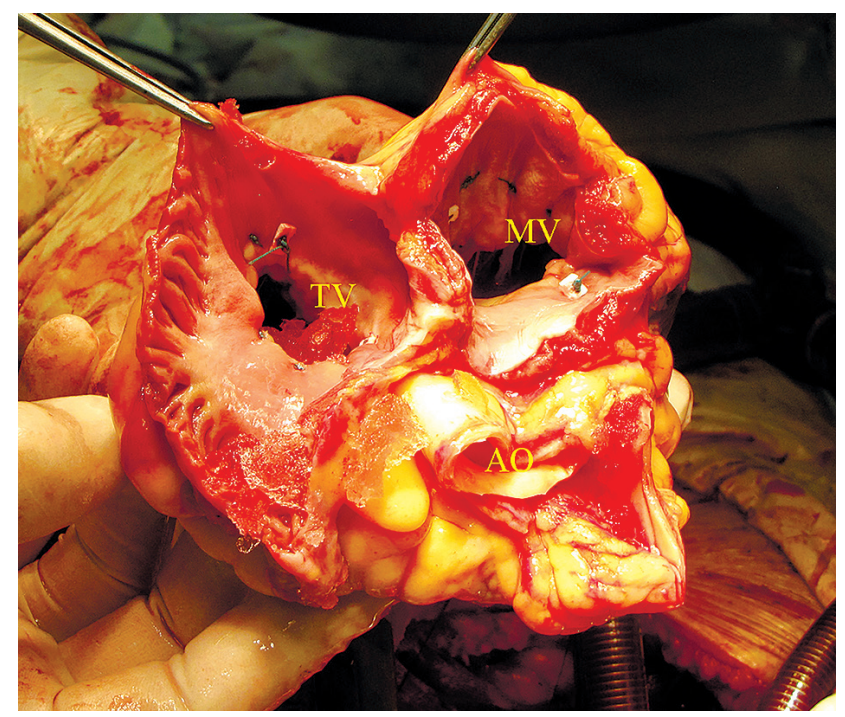

Fig. 7. Explanted heart after suture plasty of mitral and tricuspid valves

HA with signs of acute respiratory distress syndrome and sepsis. Pathology study revealed leiomyosarcoma GII (R1).

\section{Surgical technique}

One case $(1 / 5,20 \%)$ involved debulking surgery with partial resection of the LA wall and its reconstruction using a xenopericardium patch. Orthotopic heart transplantation was performed in 1 patient $(1 / 5,20 \%)$ and $\mathrm{HA}$ in the 3 other cases $(3 / 5,60 \%)$. Medial longitudinal sternotomy was used for the surgical approach in all the cases. Surgical debulking was performed under normothermic body perfusion and cold blood cardioplegia in 1 case $(1 / 5,20 \%)$; Custodiol solution was used in the remaining 4 cases $(4 / 5,80 \%)$. Left atrium reconstruction using a xenopericardium patch was performed in all 5 cases. Heart autotransplantation was performed according to the previously described technique [9, 12]. Heart autotransplantation was performed with hypothermic perfusion (280) in the first case $(1 / 3,33.3 \%)$, with normothermic perfu- 
sion in the other 2 cases $(2 / 3,66.7 \%)$. A blood autoreinfusion system (cell-saver) was also used in all cases.

Mid-term results were obtained during repeated in-hospital examination of patients.

\section{Statistical analysis}

Statistical analysis of the data was performed using the SPSS-20 software package. Arithmetic mean with standard error of the mean $(M \pm S E M)$ was used for continuous variables. Categorical data were presented as fractions and percentages.

\section{Results}

Mean myocardial ischemia (MIsc) duration was 165.6 \pm 12.0 minutes (range: 137-198), cardiopulmonary bypass (CPB) duration was $248.6 \pm 36.6$ minutes (range: 188-392), and intervention duration was $498.0 \pm 77.4$ minutes (range: 330-780). Mitral valve replacement using a biological or mechanical prosthesis was performed in 1 case $(1 / 5,20 \%)$, coronary artery bypass grafting was performed in 1 case $(1 / 5,20 \%)$, and left lower lobectomy in 1 case. Intraoperative blood loss was $1526 \pm 285.4 \mathrm{ml}$ (range: $710-2480)$, postoperative blood loss was $896 \pm 401.4 \mathrm{ml}$ (range: $250-2410$ ), and total blood loss was $2432 \pm 616.5 \mathrm{ml}$ (range: 1610-4880). Respiratory support duration after the major surgery was $217.8 \pm 76.5$ minutes (range: 10-480). Major hospital complications (grade IIIb-V Clavien-Dindo grading) were registered in 4 patients (4/5, 80\%): from 1 to 3 complications in each patient (described below). In-hospital mortality occurred in 3 patients (3/5, 60\%), 2 without receiving $\mathrm{HA}$.

Sarcoma was verified in $4(4 / 5,80 \%)$ cases: malignant fibrous histiocytoma in 2 cases (2/5, 40\%), and leiomyosarcoma and osteosarcoma in 1 case each $(1 / 5,20 \%)$. Heart lymphoma was diagnosed in 1 case (1/5, 20\%). After 4 radical interventions, R0 and R1 interventions were each confirmed in 2 patients (2/4, 50\%).

The female patient with osteosarcoma of the heart, after she had undergone debulking surgery with partial resection of the LA wall and its reconstruction using a xenopericardium patch, died on day 4 as a result of continuous bleeding and multiorgan failure. Another patient with PMMTLA died on day 13 after orthotopic heart transplantation, against the background of extensive hepatocellular necrosis. The patient was diagnosed with massive primary heart lymphoma (RO).

Survival duration in 2 patients $(2 / 5,40 \%)$ discharged from the hospital (both after HA) was 29 and 9 months, respectively. Both died because of disease progression.

Of the 5 described cases, below we report $3(3 / 5,60 \%)$ cases concerning patients with massive sarcoma of the left atrium receiving $\mathrm{HA}$.

\section{Discussion}

Sarcoma is the most common malignant tumor of the LA [2]. It is characterized by aggressive growth and therefore is usually diagnosed at advanced stages, causing heart failure symptoms and blood flow obstruction, associated with dyspnea and syncopal conditions. In our series, in 2 of the 3 patients (cases 1 and 3) both these symptoms were present. In 1 more case (\#2) the female patient was initially referred to another medical institution and was believed to suffer heart myxoma. Invasive tumor growth in this case was revealed only intraoperatively, and only a debulking approach was used. In patients with suspicion of large myxoma, thorough patient examination, including cardiac CTA and MRI (cardiosynchronized scanning), coupled with other study methods, where required, should be included in routine cardiosurgical hospital practice, allowing one in these cases both to exclude malignancy of the tumor and presence of distant metastases, and also to define tumor resectability and the extent of intervention.

Large tumors commonly involving the mitral valve and in some cases the PV ostia render radical surgery in situ impossible. Orthotopic heart transplantation in patients with PMMTLA is associated with such limitations as scarcity of donor hearts and unknown long-term results [13]. One study showed that in a group of 21 patients with PMMTLA 13 died because of distant metastases or disease recurrence [8], while another study showed that the median survival in patients with PMMTLA was 11 months [14].

Heart autotransplantation is the surgical method of choice for the treatment of patients with PMMTLA. This method promotes a direct view of the tumor resection area, does not impose the necessity for a donor heart, does not require subsequent immunosuppression, and in combination with PCT is associated with a twofold increase of survival time compared to surgically untreated patients [7]. In the largest study to date [15], 1- and 2-year survival rates in 34 out of 35 cases with HA were $46 \%$ and $28 \%$, respectively. The authors' conclusion is also of interest, stating that for primary sarcomas of the heart, microscopically positive (R1) and negative (RO) resection margins do not influence the long-term patient survival. According to other authors [16, 17], even after pathologically proven radical tumor resection (RO) local recurrence of primary malignant tumor of the left atrium is one the leading causes of mortality in the early and midterm follow-up period, and is the main indication for reintervention $[18,19]$. However, following the principles of oncology, we as well as the majority of other authors [9, 17-19] strongly believe that only a total tumor resection (RO) allows prevention of tumor recurrence in the early and midterm period. In our study both patients discharged from hospital (cases 1 and 2) had the same pathological tumor type (malignant fibrous histiocytoma GIII). They survived 9 and 29 months (mean: 19 months) after the intervention and died because of disease progression. Adjuvant PCT and radiotherapy were not performed for the patient (case 2) with pathologically proven radical $\mathrm{RO}$ repeated resection, and she died after 9 months with distant metastases and local tumor recurrence in the LA. This patient after the first nonradical surgical intervention with subsequent adjuvant PCT survived 38 months before the appearance of clinical signs of continued tumor growth necessitating re-operation. Radiotherapy was performed with total radiation dose (TRD) 
40 Gy for the second patient (case 1) after pathologically proven R1 resection of the LA wall, and he died 29 months after with distant metastases without obvious signs of continued local tumor growth. Despite all data controversies regarding the efficacy of neoadjuvant and adjuvant PCT $[7,20,21]$ and the efficacy of radiotherapy $[22,23]$ in this setting, the abovementioned facts make us prone to use these methods, depending on the results of the pathology study. Possibly, that intraoperative surgical strategy should be more radical in regard to resection of the left atrial wall, leaving the tumor resection margin more than $1-2 \mathrm{~cm}$, and maximizing where possible the resected portion of the LA wall with the mitral valve and PV ostia.

Ramlawi et al. [15], according to the results of their study, suggested that pneumonectomy in addition to HA significantly increases hospital mortality (43\% vs. $11 \%)$. In our study we also recorded 1 in-hospital lethal case (case 3) in a patient after heart autotransplantation in combination with lung resection (lower left lobectomy), performed because of leiomyosarcoma invasion into the left lower PV. We suggest that this surgical strategy should not be associated with such a dramatic increase of hospital mortality, despite the necessity of extended intervention and the aim to achieve radical tumor resection with lung resection, in cases where the tumor invades the PV. Our case was associated with a certain deficiency of our surgical strategy choice - lower left lobectomy and HA were performed using the same surgical approach (median midline sternotomy), making it difficult to perform a visual inspection of the left lung root after disconnecting the heart-lung machine and precluding the chance to find a source of bleeding in this area. On day 1 after the intervention because of continued internal bleeding the patient underwent repeated sternotomy, extended with left lateral thoracotomy. By that time massive blood loss and blood transfusions caused disseminated intravascular coagulation (DIC) syndrome, acute renal failure, and acute respiratory distress syndrome (ARDS) with subsequent sepsis, resulting in the patient's death. We suggest that avoiding certain faults in the treatment strategy will change the rate of hospital mortality after HA combined with lung resection. This suggestion is confirmed by our experience in simultaneous cardiosurgical interventions combined with lung resection in patients with lung cancer (61 patients, 29 pneumectomies, 32 lobectomies) with a hospital mortality rate of $11.45 \%$.

Such interventions may be associated with major perioperative blood loss, which in turn is associated with hospital mortality, especially in patients requiring additional lung resection [24]. In our series mean intraoperative blood loss was $1860 \mathrm{ml}$, and total blood loss was $2936 \mathrm{ml}$. In order to prevent massive blood transfusion syndrome and associated perioperative complications, we consider the following aspects to be essential: primary hemostasis starting from the very beginning of the intervention, use of a cellsaver machine, and use of a surgical approach allowing sufficient revision of all the intervention area in order to reveal any source of bleeding at any stage of the intervention.
The surgical technique for HA is well known [9, 12]. Heart autotransplantation intervention may be performed using one of two approaches: the first one is an extracorporeal resection of the affected portion of the LA wall (used in the second case presented); the second one is an explantation of unaffected heart compartments (used in the third case presented) with subsequent intracorporeal resection of the affected LA portion with possible resection of other anatomical structures and organs (lung, esophagus, etc.). Combination of the two described approaches is also possible (used in the first case presented). Large LA wall defects are generally repaired using xenopericardium patches. One case of LA wall repair using an allograft is described in the literature [19]. We suggest that this method does not provide additional benefits, as evidenced by mortality in this clinical case, resulting from continued bleeding and multiple organ failure on day 8.

At the completion of the HA intervention [12, 25], surgeons commonly encounter a tissue deficit (shortage, shortfall, deficiency), making it difficult to perform bicaval anastomosis, as opposed to the bicaval method of orthotopic heart transplantation. As a solution under such conditions, upper and lower venae cavae can be elongated using a vascular prosthesis [12] and a xenopericardium patch can be used to repair a right atrium deficit [25]. In our reviewed series, a tissue deficit for bicaval anastomosis was observed in 2 of the 3 cases (cases 1 and 2). Elongation of the upper vena cava was performed in the first case, using an intraoperatively made xenopericardium vascular prosthesis, and in the second case lower vena cava repair was performed using a xenopericardium patch. The possibility of excessive tension of bicaval anastomosis should also be considered when performing heart autotransplantation, and appropriate preventive measures should be applied.

\section{Conclusions}

Surgical treatment in patients with PMMTLA is possible in a highly selective group, but is associated with high incidence of major hospital complications and mortality. Heart autotransplantation is the surgical method of choice for the treatment of patients with PMMTLA. Nevertheless, it is commonly associated with major hospital complications and hospital mortality. The role of adjuvant PCT and radiotherapy after pathomorphological assessment of the resected tissues is not fully studied. Heart autotransplantation intervention, especially in patients with concomitant lung resection because of tumor invasion in PV, requires thorough primary hemostasis, and the surgical approach must be chosen allowing visualization of the whole intervention area throughout all steps of the intervention. The possibility of excessive tension and bleeding in the area of the bicaval anastomosis should be considered when performing HA, and appropriate preventive measures should be applied.

\section{Disclosure}

Authors report no conflict of interest. 


\section{References}

1. Lobo A, Lewis JF, Conti CR. Intracardiac masses detected by echocardiography: case presentation and review of the literature. Cardiol Clin 2000; 23: 702-708.

2. Straus R, Merliss R. Primary tumours of the heart. Arch Pathol Lab Med 1945; 39: $74-80$.

3. Shanmugam G. Primary cardiac sarcoma. Eur J Cardiothorac Surg 2006; 29: 925-932.

4. Shapiro LM. Cardiac tumours: diagnosis and management. Heart 2001; 85: 218-222.

5. Burke AP, Cowan D, Virmani R. Primary sarcomas of the heart. Cancer 1992; 69: 387-395.

6. Orlandi A, Ferlosio A, Roselli M, Chiariello L, Spagnoli LG. Cardiac sarcomas: an update. J Thorac Oncol 2010; 5: 1483-1489.

7. Putnam JB Jr, Sweeney MS, Colon R, Lanza LA, Frazier OH, Cooley DA. Primary cardiac sarcomas. Ann Thorac Surg 1991; 51: 906-910.

8. Gowdamarajan A, Michler RE. Therapy for primary cardiac tumors: is there a role for heart transplantation? Curr Opin Cardiol 2000; 15: 121-125.

9. Conklin LD, Reardon MJ. Autotransplantation of the heart for primary cardiac malignancy: development and surgical technique. Tex Heart Inst J 2002; 29: 105-108.

10. Clark DA, Quint RA, Mitchell RL, Angell WW. Coronary artery spasm. Medical management, surgical denervation, and autotransplantation. J Thorac Cardiovasc Surg 1977; 73: 332-339.

11. Cooley DA, Reardon MJ, Frazier OH, Angelini P. Human cardiac explantation and autotransplantation: application in a patient with a large cardiac pheochromocytoma. Tex Heart Inst J 1985; 12: 171-176.

12. Reardon MJ, DeFelice CA, Sheinbaum R, Baldwin JC. Cardiac autotransplant for surgical treatment of a malignant neoplasm. Ann Thorac Surg 1999; 67: 1793-1795.

13. Jiménez Mazuecos JM, Fuentes Manso R, Segovia Cubero J, Toquero Ramos J, Oteo Domínguez JF, Alonso-Pulpón Rivera L. Is heart transplantation for primary cardiac sarcoma a useful therapeutic option? Rev Esp Cardiol 2003; 56: 408-411.

14. Mayer F, Aebert H, Rudert M, Königsrainer A, Horger M, Kanz L, Bamberg M, Ziemer G, Hartmann JT. Primary malignant sarcomas of the heart and great vessels in adult patients - a single-center experience. Oncologist 2007; 12: 1134-1142.

15. Ramlawi B, Al-Jabbari O, Blau LN, Davies MG, Bruckner BA, Blackmon SH, Ravi V, Benjamin R, Rodriguez L, Shapira OM, Reardon MJ. Autotransplantation for the resection of complex left heart tumors. Ann Thorac Surg 2014; 98: 863-868.

16. Okita Y, Miki S, Ueda Y, Tahata T, Sakai T, Matsuyama K. Recurrent malignant fibrous histiocytoma of the left atrium with extracardiac extension. Am Heart J 1994; 127: 1624-1628.

17. Gabelman C, Al-Sadir J, Lamberti J, Fozzard HA, Laufer E, Replogle RL, Myerowitz PD. Surgical treatment of recurrent primary malignant tumor of the left atrium. J Thorac Cardiovasc Surg 1979; 77: 914-921.

18. Iskander SS, Nagueh SF, Ostrowski ML, Reardon MJ. Growth of a left atrial sarcoma followed by resection and autotransplantation. Ann Thorac Surg 2005; 79: 1771-1774.

19. Malyshev M, Safuanov A, Gladyshev I, Trushyna V, Abramovskaya L, Malyshev A. Primary left atrial leiomyosarcoma: literature review and lessons of a case. Asian Cardiovasc Thorac Ann 2006; 14: 435-440.

20. Reardon MJ, Walkes JC, Benjamin R. Therapy insight: malignant primary cardiac tumors. Nat Clin Pract Cardiovasc Med 2006; 3: 548-553.

21. Herrmann MA, Shankerman RA, Edwards WD, Shub C, Schaff HV. Primary cardiac angiosarcoma: a clinicopathologic study of six cases. J Thorac Cardiovasc Surg 1992; 103: 655-664

22. Movsas B, Terya-Feldstein J, Smith J, Glatstein E, Epstein AH. Primary cardiac sarcoma: a novel treatment approach. Chest 1998; 114: 648-652.

23. Hamidi M, Moody JS, Weigel TL, Kozak KR. Primary cardiac sarcoma. Ann Thorac Surg 2010; 90: 176-181.

24. Blackmon SH, Patel AR, Bruckner BA, Beyer EA, Rice DC, Vaporciyan AA, Wojciechowski Z, Correa AM, Reardon MJ. Cardiac autotransplantation for malignant or complex primary left-heart tumors. Tex Heart Inst J 2008; 35 296-300

25. Wu JT, Frazier OH, Nasser MM, Reul RM. A novel surgical approach to cardiac autotransplantation in complex cardiac sarcoma resection. Innovations 2010; 5: 364-368. 